\title{
Research on Basic Competence Elements of Undergraduates Majoring in Engineering Cost: A Case Study of Mainland China
}

\author{
Hua ZHAO ${ }^{1, a,{ }^{*}}$, Li-feng ZHANG ${ }^{1, b}$ and Hui-jie JIANG ${ }^{2, c}$ \\ ${ }^{1}$ School of Accounting, Wuhan Textile University, Hubei, China \\ ${ }^{2}$ School of Construction and Environmental Engineering, Shenzhen Polytechnic, \\ Guangdong, China

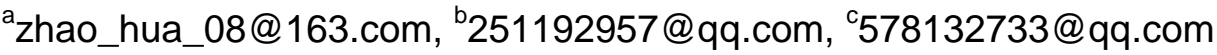 \\ ${ }^{*}$ Corresponding author
}

Keywords: Basic Competence Elements, Engineering Cost, Mainland China.

\begin{abstract}
The level of basic competence of college students is an important guarantee for the realization of smooth employment, and it is also one of the important indicators of the ability to a university or a college. On the basis of the literature review, this paper compares the basic competence standard system of some typical national and regional professionals in the field of quantity surveying, summarizes and abstracts its core elements, and constructs a basic competence elements system of the undergraduates majoring in engineering cost in Mainland China in view of the industry situation, which have some guiding significance to the optimization and reform of the training mode of related majors in mainland China.
\end{abstract}

\section{Introduction}

The higher education of engineering cost (EC) major in Mainland China is experiencing significant changes from scale expansion to structural adjustment. The employment situation of the professional graduates majoring in $\mathrm{EC}$ has disappeared, the structure of the employment difficult problem is increasingly apparent. Obviously, the key to the smooth employment of undergraduates is that their professional basic competence level meets the needs of the industry market. For the relevant universities in mainland China, how to improve the professional undergraduate's basic competence to respond to the needs of the talent market, is becoming an important reform path of its talent training model. From the practical point of view, it is necessary to analyze and construct the basic competence elements standard which meets the demand of the talent market, design the matching training system and ensure its effective operation, which will become the central task that relevant universities should always carry out. Based on the benchmarking method, this paper summarizes and constructs a proposal program on the basic competence elements standard for undergraduates majoring in EC in mainland China by comparing and analyzing the basic competence standard system of some national and regional professionals in the field of quantity surveying (QS), which provide an exploratory guidance for the above topic.

\section{Literature Review}

With the rapid development of China's construction industry, the higher education scale of EC in mainland China is expanding very rapidly, which results in the relevant research on the higher education concepts and patterns of EC is very active. Yi-ling 
YING and Juan BAI suggested that the cultivation of application talents who meet the needs of the market is the primary task of the training of the EC major, and construction the competence standard of EC professionals can be constructed from the connotation and quality characteristics of the applied EC professionals [1]. Qi ZHANG et al. pointed out that the university talents training must meet the requirements of the enterprise job ability in order to achieve professional training objectives [2]. From the perspective of the cost engineer certification system, Jie LI et al. analyzed the knowledge structure and practical ability of the cost engineer, summarized the basic requirements of the EC management, and pointed out that the major training program should be adjusted and optimized based on the social development trends and the new professional competence standards of cost engineers [3][4]. Xiao-fang WANG summed up by the post research that EC staff must have three kinds of abilities including the basic practice literacy, job skills and comprehensive professional competence [5]. Obviously, it is an important idea to construct the basic competence standard of undergraduates majoring in EC from the professional demanding. There are many research results similar to the above, for example Yan-yan WANG et al. [6], Shu-qi ZHAN [7], etc. Systematic research results began in Ling YAN et al., they systematically summarized some relatively mature occupational competence standards about QS abroad, and put forward that the exploration of Chinese EC professional competence standard should be in line with the international trend and also reflect China's national conditions [8][9]. In summary, for the study on Chinese EC professionals training mode, taking the international benchmarks and the actual needs of the Chinese market into account comprehensively has become the mainstream academic viewpoints.

Table 1. The analysis of QS basic competence elements in typical countries and regions

\begin{tabular}{|c|c|c|c|}
\hline & RICS & PAQS & HKIS \\
\hline 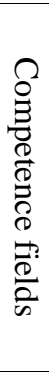 & $\begin{array}{l}\text { 1)Rules of conduct } \\
\text { 2)Professional ethics } \\
\text { 3)Conflict management } \\
\text { 4)Data \& information } \\
\text { 5)Customer relationship } \\
\text { 6)Communication } \\
\text { 7)Negotiation, teamwork } \\
\text { 8)Business management } \\
\text { 9)Law \& public relations }\end{array}$ & $\begin{array}{l}\text { 1)Measuring } \\
\text { 2)Communication } \\
\text { 3)Teamwork } \\
\text { 4)Information technology } \\
\text { 5)Interpersonal skills } \\
\text { 6)Business management } \\
\text { 7)Construction technology } \\
\text { 8)Construction economy } \\
\text { 9)Laws and regulations }\end{array}$ & $\begin{array}{l}\text { 1)Measurement } \\
\text { 2)Construction techniques } \\
\text { 3)Business management } \\
\text { 4)Professional practice } \\
\text { 5)Laws and regulations } \\
\text { 6)Communication } \\
\text { 7)Personal and } \\
\text { interpersonal } \\
\text { 8)Information technology }\end{array}$ \\
\hline 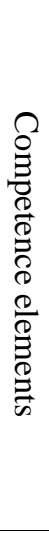 & $\begin{array}{l}\text { 1)Professional practical ability } \\
\text { 2) Professional ethics } \\
\text { 3)Conflict avoidance or disputes } \\
\text { resolution } \\
\text { 4)Data management and } \\
\text { information skills } \\
\text { 5)Customer relationship } \\
\text { maintenance skills } \\
\text { 6)Written or oral skills } \\
\text { 7)Negotiation skills } \\
\text { 8)Teamwork skills } \\
\text { 9)Business management skills } \\
\text { 10)Law \& public relations }\end{array}$ & $\begin{array}{l}\text { 1)Measuring ability } \\
\text { 2) Communication skills } \\
\text { 3) Teamwork skills } \\
\text { 4)Computer, information } \\
\text { technology } \\
\text { 5) Interpersonal skills } \\
\text { 6) Business management } \\
\text { skills } \\
\text { 7)Construction technology } \\
\text { 8)Construction economy } \\
\text { 9)Laws and regulations }\end{array}$ & $\begin{array}{l}\text { 1) Measuring ability } \\
\text { 2) Construction technology } \\
\text { 3)Business management } \\
\text { skills } \\
\text { 4)Professional practical } \\
\text { ability } \\
\text { 5)Construction laws and } \\
\text { regulations } \\
\text { 6) Communication skills } \\
\text { 7)Self-management and } \\
\text { interpersonal skills } \\
\text { 8)Computer, information } \\
\text { technology }\end{array}$ \\
\hline 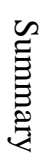 & \multicolumn{3}{|c|}{$\begin{array}{l}\text { 1) Professional ethics, 2) Project measuring ability, 3) Construction technology, } \\
\text { 4) Construction laws and regulations, 5) Construction economy and business management, } \\
\text { 6) Teamwork skills, 7) Self-management and interpersonal skills, 8) Negotiation skills, } \\
\text { 9) Data management and information technology, 10) Communication skills. }\end{array}$} \\
\hline
\end{tabular}




\section{Analysis on Basic Competence Standard of QS in Typical Countries and Regions}

Internationally, the development of the QS competence standard system is generally the responsibility of the industry association in developed countries or regions. At present, the more mature systems are developed mainly by RICS (Royal Institution of Chartered Surveyor), PAQS (Pacific Association of Quantity Surveyors), HKIS (THE HONG KONG INSTITUTE OF SURVEYORS), etc. The specific competence contents of surveyor or cost engineer are difference among the different countries or regions, but there is a common characteristic to construct the professional competence requirements. The QS professional competence standard all includes three levels: compulsory ability requirement, core ability requirement and expert ability requirement [9]. Selecting the above three as the benchmark, the QS basic competence elements of typical countries and regions can be summarized in Table 1 .

As shown in Table 1, the construction of QS basic competence system in typical countries and regions can be summarized some dimensions as following:

A. Basic character and quality. This competence dimension mainly includes complying with industry rules, good professional ethics, effective self-management and interpersonal skills, skilled modern information technology and so on.

B. Professional knowledge. This part mainly covers serial competencies such as measurement knowledge of different professional projects, conventional project construction techniques, relevant construction laws and regulations, professional knowledge of construction economy and management, etc.

C. Professional skills. This section mainly includes some specialized skills by professional training, for example project measuring ability, teamwork skills and negotiation skills, and communication skills, etc.

\section{Construction of Basic Competence Elements for Undergraduates Majoring in EC}

\section{Analysis on Development Trend of Chinese EC Consulting Industry}

The Chinese consulting industry is still in the stage of rapid development and its practical situations differ from which in the developed countries or regions. Therefore, the direct use of the QS competence system in typical countries or regions cannot adapt to the demanding of EC professionals training for the relevant universities in China. The Chinese industry situation and its development tendency must be taken into account in the design of basic competence elements for undergraduates majoring in EC, which is characterized as follows:

A. Diversification of professional engineering and its implementation regulation is not uniform. In China, construction projects are subdivided into housing construction, civil engineering, municipal gardens, bridges and tunnels, ports and other different professional projects. There are existing different implementation methods and different professional techniques standards in different professional projects. Therefore, for the EC consultants, they have a wide range of practice areas that require diverse and segmented expertise.

B. Engineering consulting firms require graduates to adapt to job requirements as quickly as possible, with a particular focus on practical skills. At present, the homogeneity of Chinese engineering consulting enterprises is common, the price war has become an important business strategy, which results in the utilitarian idea of hiring employees is obvious, the enterprise specially emphasis on the practical ability of graduates. 
C. The calculation of engineering quantities and the confirmation of project prices are still the main business areas of graduate employment. In the planned economy era, the EC management business in mainland China is mainly confined to the cost planning and control of construction projects. Although the functions of the EC management are no longer single with the deepening of market economic system reform, the scope of its business is still relatively narrow compared with foreign counterparts. For many fresh graduates, the calculation of engineering quantities, cost estimating and cost control are still the main business in long time.

Table 2. The basic competence elements system for undergraduates majoring in EC

\begin{tabular}{|c|c|c|}
\hline Dimension & Competence elements & Specific indicators// Characterization \\
\hline \multirow{9}{*}{ 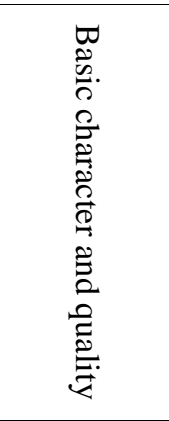 } & \multirow{5}{*}{$\begin{array}{l}\text { Physical and mental } \\
\text { qualities }\end{array}$} & Good physical fitness, no disease \\
\hline & & Positive working attitude \\
\hline & & Independent, able to take responsibility \\
\hline & & Honest and trustworthy \\
\hline & & Good professional ethics \\
\hline & self-management & Good management of their own health, emotions, etc \\
\hline & interpersonal skills & Good at dealing with others \\
\hline & \multirow[b]{2}{*}{ Information technology } & Proficiency in the use of conventional office software \\
\hline & & $\begin{array}{c}\text { Familiar with some professional software for calculating } \\
\text { quantities, cost estimating and so on }\end{array}$ \\
\hline \multirow{7}{*}{ 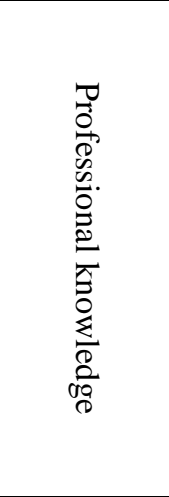 } & Engineering survey & $\begin{array}{l}\text { Familiar with the measurement regulations and } \\
\text { techniques for different professional engineering }\end{array}$ \\
\hline & Construction techniques & $\begin{array}{l}\text { Understand the construction process and methods of } \\
\text { construction projects }\end{array}$ \\
\hline & Laws and regulations & $\begin{array}{c}\text { Be familiar with construction laws and regulations and } \\
\text { keep eyes on their changes }\end{array}$ \\
\hline & Construction economy & Comprehensive project finance management knowledge \\
\hline & Engineering management & System engineering management expertise and methods \\
\hline & Cost management & $\begin{array}{l}\text { Familiar with principles, procedures and methods of } \\
\text { project cost management }\end{array}$ \\
\hline & Business management & $\begin{array}{l}\text { Learn a certain knowledge about business development, } \\
\text { contract negotiation and business management }\end{array}$ \\
\hline \multirow{7}{*}{$\begin{array}{l}\overrightarrow{0} \\
\overrightarrow{0} \\
\overrightarrow{0} \\
0 \\
0.0 \\
0 \\
0 \\
0 \\
0 \\
0.0 \\
\overline{0}\end{array}$} & \multirow{3}{*}{ Engineering survey } & Able to read different professional engineering drawings \\
\hline & & Use the software to calculate project quantities \\
\hline & & Able to compile the bill of quantities \\
\hline & Teamwork & Good collaboration with others, a sense of team mission \\
\hline & Negotiation & A certain business negotiating skills \\
\hline & Contract management & Good contract theory and flexible management skills \\
\hline & Communication & $\begin{array}{l}\text { Good at communicating with others, able to handle } \\
\text { disputes or contradictions }\end{array}$ \\
\hline
\end{tabular}

D. The informatization of the engineering consulting services is very rapid. In recent years, the EC consulting industry continues to improve the level of informatizaon in mainland China, a large number of professional software has become the industry's conventional tools, especially BIM (Building Information Modeling), VR (Virtual Reality) and other new technologies continue to apply in the traditional EC consulting industry, which will bring unprecedented challenge for graduates majoring in EC.

\section{Design of Basic Competence Elements for Undergraduates Majoring in EC}

One of the successful experiences of China's reform and opening up is to combine the universal truth with China's concrete practice. For the design of the basic competence elements for undergraduates majoring in EC, both the general practice of some typical countries or regions and China's specific realities must be considered simultaneously. 
According to this idea, the basic competence elements system for undergraduates majoring in EC is shown in Table 2.

\section{Conclusion}

In mainland China universities, professional construction is greatly affected by the talent market demand. Universities and their teachers should consistently study and optimize professional training programs to improve the response of graduates to the talent market demand. Given the grim employment situation for more and more graduates majoring in EC in mainland China, This paper attempts to solve the problem by optimizing the professional training program. At first, this paper compared the basic competence standards in typical countries and regions, and summarized their standards as three dimensions: basic character and quality, professional knowledge and professional skills. And then, the concrete practice and its development tendency of EC consulting industry in mainland China are analyzed. Finally, this paper constructs a basic competence elements system for undergraduates majoring in EC, which has some guiding significance to the professional training program optimization of $\mathrm{EC}$ in mainland China.

\section{References}

[1] Yi-lin YIN, Juan BAI, Exploration and Practice on Applied Professional Training Model of Project Cost: A Case Study of Tianjin University of Technology, J. China Engineering Science, 1 (2015) 114-119.

[2] Qi ZHANG, et al. Teaching Reform for Construction Cost Talents Cultivation Modes Based on Job Requirements of Enterprises, J. The Science Education Article Collects, 21 (2015) 54-55.

[3] Jie LI, Professionals Management System and Training of Application Students: Taking Cost Engineering Major as an Example, J. Journal of Architectural Education in Institutions of Higher Learning, 3 (2008) 7-10.

[4] Jie LI, Yuan-fang LIU, Study on the Training Standard of Application-oriented Cost Engineering Professional, J. Journal of Fujian University of Technology, 5 (2009) 431-436.

[5] Xiao-fang WANG, Study on the Practice Teaching System of Engineering Cost based on Professional Competence, J. Survey of Education, 34 (2014) 46-47,52.

[6] Yan-yan WANG et al. Talent Training of Engineering Cost Based on Abilities, J. Journal of Architectural Education in Institutions of Higher Learning, 4 (2009) 46-49.

[7] Shu-qi ZHAN, Study on Professional Course System for Engineering Cost Based on the Model of Competencies, J. Xiamen Science \& Technology, 6 (2014) 54-59.

[8] Lin YAN et al. Research on Studio Practice Teaching Based on Competence Standards: Taking the Engineering Cost Major of Tianjin University of Technology as an Example, J. Modern Educational Technology, 6 (2014) 113-121.

[9] Lin YAN, Yi-lin YIN, Study on Professional Certification System: Based on the Sample Analysis of the Quantity Surveying Major in Britain and Asian-Pacific regions, first ed., Tsinghua University Press, Beijing, 2013. 